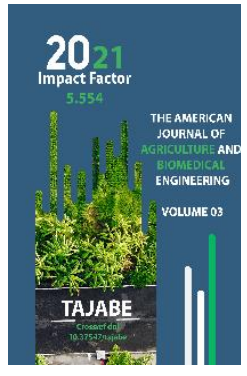

Journal Website: https://theamericanjou rnals.com/index.php/ta jabe

Copyright: Original content from this work may be used under the terms of the creative commons attributes 4.0 licence.

\section{Growing A Lemon In Trenches And Protecting Against Pests}

\author{
Dilshod Obidzhanov \\ Doctor Of Philosophy Of Agricultural Sciences, Laboratory Manager, Scientific-Research \\ Institute Of Horticulture, Viticulture And Winemaking Named After Academician Makhmud \\ Mirzaev, Uzbekistan
}

Mirkhatam Mirzaev

Doctor Of Philosophy Of Agricultural Sciences, Laboratory Manager, Uzbekistan

\title{
ABSTRACT
}

It is recommended in the state that varieties of lemon in citrus fruits apply the correct agronomic measures in broad transcripts, obtain high yields from them, add weight value and improve and prevent hazards. Of the following insecticides per 10 liters of water against whitefly in lemon: Entoluxo 20\% - 10 g, Entospilan 20\% - 15 g, Agrofos Extra 60\% - 4 g, Dalat plus 10\% - 5 g. We recommend one of the drugs for taking antidepressants. High biological effectiveness is achieved when these preparations are used 2-3 times a day by spraying during the growing season.

\section{KEYWORDS}

Citrus Fruits, Lemon, Agronomic, Biology, Insecticides, Ways Of Protection, Efficiency.

\section{INTRODUCTION}

The development of the Republic of Uzbekistan and the growing population are increasing the demand for food, especially fruits and processed products, their type and quality. It is no exaggeration to say that the demand for citrus fruits and their processed products, in particular, is the most popular among all other fruit crops.
Consequently, fresh lemons and unique juices made from them have become one of the daily foods of the population of many foreign countries. The widespread and valuable distribution of lemons is due to their unique taste, vitamin richness, fragrant aroma, suitability for processing, storage and transportation, simplicity of cultivation and 
The American Journal of Agriculture and Boimedical Engineering

(ISSN - 2689-1018)

IMPACT FACTOR

Published: December 30, 2021| Pages: 15-18

Doi: https://doi.org/10.37547/tajabe/Volume03Issue12-04

2021: 5.554

OCLC - 1121105746

reproduction, and a number of similar advantages.

In recent years, the demand for lemons and their by-products (juice, marmalade, candied fruit, essential oils, etc.) has increased significantly in Uzbekistan. In this regard, the approach to the cultivation of lemon in the conditions of the Republic has changed radically.

Therefore, the Resolution of the Cabinet of Ministers of the Republic of Uzbekistan dated December 24, 2009 No 03-30-68 "On measures to develop the cultivation of subtropical crops in Uzbekistan" was adopted. tasks of organization of reproduction and cultivation procedures on a scientific basis have been identified.

Citrus plants were brought to Uzbekistan in the second half of the 2oth century and began to be grown in greenhouses and ditches.

In 1966 at the R.R. Schroeder Research Institute of Horticulture, Viticulture and Enology 0.30 ha. A greenhouse was built on the site and a collection of citrus plants was established in these greenhouses by scientist E.S. Chikhotua. At the same time, ditches were dug near the greenhouse, where lemon seedlings were planted.

Citrus plants in our country in 1949-1954 by A.Ya. Zaretsky, in 1968-1978 by MA Khudzinsky, ES Chkhotua and in 1966-1996 by Yu.l. Zeytsev, MA Arslanov. , varieties of grapefruit and pampelmus were introduced, and in addition to scientific research, they also carried out research work on selection.

Place And Technique Of Researches
Monitoring of susceptibility to infection of a potato by pests was spent all over the territory of the Republic, and experiments and routing supervision were held on fields of Tashkent regions. In research work the various methods recommended for these purposes (Gar, 1974; Dospekhov, 1979; Recommendations of Biological Monitoring Department of SRI, 1986; Khodzhaev, 2004) have been used.

Scientific work was carried out on the basis of the method developed at the Research Institute of Horticulture, Viticulture and Enology named after Academician M. Mirzaev. Scientific research was carried out on 2 varieties of lemons in wide ditches. The area of the wide trench is 0.25 ha, length $100 \mathrm{~m}$, width $6 \mathrm{~m}$, wall height $5 \mathrm{~m}$, concrete wall thickness $0.2 \mathrm{~m}$. The walls and roof are made of steel construction and covered with polyethylene film. The seedlings were grafted on two-yearold lemon seedlings in 1985, and the seedlings were planted in three rows, with $2 \mathrm{~m}$ between rows, $1 \mathrm{~m}$ from the wall, and $3 \mathrm{~m}$ between bushes.

\section{Results Of Experiments And Their Discussion}

Scientific observations made during 2015-2017 obtained the following results in natural conditions without artificial heating in wide trenches.

In wide ditch conditions, citrus plants began to sprout from March 10-14, mainly in lemon varieties, depending on weather conditions. At the same time, the control Meyer variety started to sprout on March 14, while the vegetation of the first Uzbek variety started 4 days ago. In the Meyer variety, flower buds began to form on March 20, flowering began 
The American Journal of Agriculture and Boimedical Engineering (ISSN - 2689-1018)

on March 31, while in the first variety of Uzbekistan, flower buds began to form on March 25, and flowering began on April 5 . Flowering time is 25 days in the first variety of Uzbekistan, 30 days in Meyer variety.
The fruits of lemons began to ripen on October 17 , and the full ripening of the fruit is 36 days, while the first variety of Uzbekistan is 49 days.

In citrus varieties, the average phenological phases

and yield are 3 years

1- table

(2015-2017 йй.)

\begin{tabular}{|c|c|c|c|c|c|c|c|c|}
\hline \multirow[b]{2}{*}{$\begin{array}{l}\text { Crop type } \\
\text { and } \\
\text { varieties }\end{array}$} & \multirow[b]{2}{*}{$\begin{array}{l}\text { The bud } \\
\text { begins } \\
\text { to open }\end{array}$} & \multirow{2}{*}{$\begin{array}{l}\text { The } \\
\text { beginnin } \\
\text { g of } \\
\text { flowering }\end{array}$} & \multirow{2}{*}{$\begin{array}{c}\text { Floweri } \\
\text { ng } \\
\text { duratio } \\
\text { n }\end{array}$} & \multirow{2}{*}{$\begin{array}{l}\text { The } \\
\text { fruits } \\
\text { begin } \\
\text { to } \\
\text { ripen }\end{array}$} & \multicolumn{2}{|c|}{ Productivity } & \multirow{2}{*}{$\begin{array}{c}\text { The } \\
\text { average } \\
\text { weight } \\
\text { of a } \\
\text { single } \\
\text { fruit }\end{array}$} & \multirow[b]{2}{*}{$\begin{array}{c}\text { Producti } \\
\text { vity ratio } \\
\%\end{array}$} \\
\hline & & & & & $\begin{array}{l}\text { Productivity } \\
\text { from one the } \\
\text { bush }\end{array}$ & t/g. & & \\
\hline \multicolumn{9}{|c|}{ Лимон } \\
\hline $\begin{array}{c}\text { Meyer } \\
\text { (control) }\end{array}$ & 14/ш & 31/ш & 30 & $17 / x$ & 13,8 & 22,7 & 89 & \\
\hline $\begin{array}{l}\text { The } \\
\text { firstborn of } \\
\text { Uzbekistan }\end{array}$ & 14/ш & $5 / \mathrm{lv}$ & 25 & $17 / x$ & 15,9 & 26,2 & 94 & \\
\hline
\end{tabular}

In 2015-2017, the average yield of lemons in the Meyer variety was $13.8 \mathrm{~kg}$ per bush, or 22.7 tons per hectare, while the first variety of Uzbekistan was $15.9 \mathrm{~kg}$ per bush and 26.2 tons per hectare. is formed. The average weight of a single fruit in the Meyer variety is $89 \mathrm{~g} .94 \mathrm{~g}$ in the firstborn of Uzbekistan. is formed.

Obtaining the above results requires the full implementation of the established agrotechnical measures and the timely control of diseases and pests.
In the Republic, lemons are damaged by diseases: gammosis, phytophthora, anthracnose, flour-dew, black spot, rust diseases and pests: greenhouse whitewash, citrus moth, soft fake shield, spider and citrus tree nematode. These pests can destroy up to $50 \%$ of the crop if timely and quality control measures are not taken.

Greenhouse effluent. The whitefly pest multiplies and damages more than 300 plants. The most harmful plants are lemon, cucumber, tomato, eggplant, parsley and celery. 
A large number of light-colored small spots are observed on the leaves of plants infested with algae. When the leaves of the plant are shaken, it can be observed that a colony of large numbers of whites has flown away. It is very difficult to see the white larvae under the leaves, because they are very small in size, as well as light in color. The leaves of plants infected with algae turn yellow and then fall off, in some cases the plant may wither.

If the pest is not controlled in time, it will cause great damage to the crop. The damage caused to plants by the whitefly pest is not limited to the absorption of plant sap, but is also a carrier of various viral, bacterial and fungal diseases.

\section{CONCLUSION}

Chemical control measures: 10 liters of water from the following insecticides: Entolucho 20\% - 10 g, Entospilan 20\% - 15 g, Agrofos Extra 60\% $4 \mathrm{~g}$, Dalate plus $10 \%-5 \mathrm{~g}$. It is recommended to treat with one of the drugs in moderation. High biological efficacy is achieved when these drugs are used 2-3 times in innocence.

As a result of research, we can conclude the following.

1. The results of the research show that it is possible to grow citrus plants in ditches and get high yields by caring for them. Lemon varieties begin to open buds from March 1 to 20, depending on the climatic conditions of the wide ditch, begin to bloom from April 1 to 20 and ripen from October 17 to November 20. It is necessary to ventilate the trenches at the time of budding and flowering.
2. In the conditions of wide ditches in Uzbekistan, lemon from citrus plants is recommended for growing Meyer and Uzbek firstborn, varieties.

In order to prevent the increase of diseases and insects in the wide ditches in the spring and autumn seasons, it is necessary to ventilate the ditches at this time and take timely pest control measures.

3. From the following insecticides per 10 liters of water against leukemia in lemon: Entolucho 20\% - 10 g, Entospilan 20\% - 15 g, Agrofos Extra 60\% - 4 g, Dalate plus 10\% - 5 g. It is recommended to treat with one of the drugs in moderation. High biological efficacy is achieved when these drugs are used 2-3 times in innocence.

\section{REFERENCES}

1. Gulomov B. Technology of growing citrus plants. Study guide. - Tashkent, 2011.

2. Kulkov O.P. Subtropical fruit cultures of Uzbekistan. T., 1969.

3. Guidelines for testing insecticides, acaricides, biologically active substances and fungicides (edited by Khojaev Sh.T.). Tashkent, 2004. - 102 p.

4. Khojaev Sh.T. Basics of combined plant protection from pests and agrotoxicology.

- Tashkent: Navruz, 2014. - 541 p.

5. Chxotua E.S. Nekotorye sposobb sovershenstvovaniya transheynoy kultury limona $v$ Uzbekistane. Abstract. Dushanbe, 1953. 